\title{
Myth and Education in the Development of Human Existence: Existential, Cultural and Social Space
}

\author{
Evgeniya V. Savelova* \\ Khabarovsk State Institute of Culture \\ 112 Krasnorechenskaia Str., Khabarovsk, 680045, Russia
}

Received 29.01.2016, received in revised form 24.03.2016, accepted 17.05.2016

\begin{abstract}
In this paper, the author presents the results of the study of myth and education as universal phenomena of human life and culture. The author refers to a number of fundamental methodological approaches that together can justify certain regularities of functioning of myth and education in the development of the human's being and his formogenesis. The article reveals the existential basis of manifestations of myth and education in the co-existential space of the human existence. The author investigated the origins and genesis of cultural being of myth and education and their meaning-making role. The article also determines specificity of semiotic representation of myth and education in the universe of cultural meanings. It analyzes the characteristics of structural-functional, dynamic and communicative aspects of the interaction of myth and education in the cultural space. It justifies the participation of myth and education in the social and communicative processes and modern educational practice.
\end{abstract}

Keywords: myth, education, human being, existence, culture, society.

DOI: 10.17516/1997-1370-2016-9-6-1345-1355.

Research area: culture studies.

\section{Introduction to the problem}

Currently, philosophical problems are actualized by the search and explication of nonclassical and post-non-classical methods and approaches to the analysis of the fundamental grounds for human existence, society and culture. This is due to the state of contemporary culture that is characterized by the increased dynamics in all its spheres and in all processes, mosaic structure, rhizomeness, semantic fragmentation and is regarded as a situation of "homelessness" (M. Buber), the "end of history" (F. Fukuyama), "proximity of things to their own images, mixing humans with their own code" (J. Baudrillard). At such moments of "destabilization" of the semantic space of culture a human gets dissolved in the external information flows, loses the life-purpose landmarks and experiences an acute shortage of existential knowledge and a self-identity crisis.

In this situation, occurs a relevant and indemand issue in the philosophical discourse, which is the reflective search for a dialogue between the different semantic fields of culture, in which there is a need for a comprehensive theoretical analysis and rethinking of those basic universals that recently have formed a solid conceptual framework of the paradigm of rationality of a classical type. Among these

(C) Siberian Federal University. All rights reserved

* Corresponding author E-mail address: savelova_ev@hgiik.ru 
universals, of course, there are myth and education that lead to the formation of a person, his outlook, values, meanings, goal sets and aspirations.

A fundamental character of education and its relevance for the formation of an integral system of the human world view and awareness of his place in the world cannot be overestimated. When educating, a person acquires personal being; through education as a kind of "membrane" he represents himself in the universe of cultural meanings; in the institutional space of education, society is resumed and reproduced as a special reality of joint being. What has been given by nature to the human being is not enough: it is in education where self-creation of a human occurs, as well as the alignment and comprehension of his own individual consciousness, his own unique image.

Myth is also understood and interpreted in a variety of research contexts as a special "machine" of culture (M.K. Mamardashvili), as a way of organizing and structuring of human powers completing and creating a person in being, in which there is no natural reason for him.

The researchers find the total presence of myth in all areas of traditional and modern culture, and spontaneous reproduction or the conscious construction of myth is recognized as an important, if not decisive, factor in the sociocultural dynamics. Mythological components are revealed in religion, in arts especially oriented towards the mass market, in economics, in politics, even in science in parascientific and quasi-scientific forms. Myth is examined as a unique way of the human world perception and meaning creation, as a mechanism for reproducing of the ethnic and cultural tradition. It is found in depths of the individual psyche as a projection of the collective socio-cultural representations, is presented as a logical tool for alleviating the fundamental ideological contradictions, is correlated with the personal spiritual self-construction, is marked in the creative-transformative and regulative functions. Mythological "logic" works in all areas of heterogeneous consciousness of a modern person, including in the area of emotional and sensory feelings, theoretical and projective thinking, creative activities, social and communicative experience.

Thus, in a research tradition there is a virtually unlimited space of various, sometimes conflicting interpretive approaches to the disclosure of definitions of "myth" and "education". In this connection, there is a problem of "blurring" of conceptual fields of myth and education, bringing integrity of their perception to the totality of private manifestations and individual forms, which interferes with the elucidation of the unifying force that the ratio for these cultural universals contains.

\section{Statement of the problem}

The present study reveals the conceptual relationships of education and myth as the two fundamental phenomena of any culture in any historical phase of its existence. In a sociohumanitarian discourse the interconnection and interdependence of these two components of human existence and culture happened to be practically missed out, which led to a number of main research questions: What are the origins and the genesis of myth and education as the most important constitutive principles of the human existence? Do myth and education have common signs of "family likeness" of concepts (L. Wittgenstein)? What role does the interaction of myth and education play in the process of formation of the human being generally and its central sense-making sphere - culture? What is the specificity of the "transition" of myth and education from one level of existence to another? Is it possible to find a mythological component in modern education and what is its positive potential? 


\section{Conceptological research grounds}

For defining a concept of this study there is a problem of philosophical understanding of the fundamental bases of being and its constituent phenomena (culture and society), the development of which has been the subject of numerous works of representatives of non-classical and post-non-classical stages of philosophizing (R. Barthes, H. Bergson, J. Baudrillard, W. Windelband, H.-G. Gadamer, N. Hartmann, F. Guattari, A. Giddens, E. Husserl, J. Derrida, W. Dilthey, G. Simmel, E. Cassirer, A.F. Losev, Iu.M. Lotman, J. Ortega y Gasset, T. Parsons, J. Habermas, M. Heidegger et al.).

Certainly, in order to reveal the research problematics there is a set of conceptual provisions about a person as a multi-dimensional, unique manifestation of "being in formation" and his co-being with the Other, the rationale of which is given in philosophical anthropology, psychoanalysis, existentialism and dialogical philosophy (L. Binswanger, M.M. Bakhtin, V.S. Bibler, O.F. Bolnov, M. Buber, B. Waldenfels, A. Gehlen, G. Deleuze, J. Lacan, E. Levinas, M.K. Mamardashvili, S.L. Frank, M. Scheler, K. Jaspers et al.).

Western European and Russian sociohumanitarianstudiesestablishedacertaintradition of considering myth based on very different methodological and theoretical approaches and in a variety of scientific perspectives-philosophical, sociological, historical, anthropological, philological, theological, semiotic, cultural, politological, psychological, communicative (N. S. Avtonomova, A.K. Baiburin, R. Barthes, G. Vico, Ia.E. Golosovker, Iu.M. Duplinskaya, L.G Ionin, E. Cassirer, A.F. Kosarev, L. Levi Bruhl, K. Levi-Strauss, A.M. Lobok, A.F. Losev, B. Malinowski, I.V. Melik-Gaikazian, V.M. Naidysh, F. Nietzsche, Iu.S. Osachenko, A.M. Piatigorskii, A.R. Radcliffe-Brown, E.B. Tylor, A.V. Ul'ianovskii, J.D. Frazer, K. Hubner, F.W. Schelling, M. Eliade, K.G. Jung et al.)
The spectrum of philosophical studies on specific aspects of education as a phenomenon of human existence, culture and society is also extremely wide. In addition to the classical philosophical tradition, the researchers addressed the problems of education in the context of philosophy of life, philosophical anthropology, social philosophy and sociology, phenomenology and hermeneutics, existentialism, dialogical philosophy. Thestudyofeducationasanindependent subject was carried out in the framework of foreign and Russian pedagogy, pedagogical anthropology and philosophy of education (O. Bol'nov, I.M. Bykhovskaia, A.P. Valitskaia, B.S. Gershunskii, S.I. Hessen, J. Derbolav, D. Dewey, V.A. Konev, D. Lenzen, M. Lipman, R. Lochner, K. Mollenhauer, H. Nohl, A.P. Ogurtsov, V.V. Platonov, A.Ia. Flier, P. Freire, S.S. Sheveleva, G.P. Shchedrovitskii, N.S. Iulina and others).

Although in the practice of traditional and modern humanitaristics, myth and education were the subject of the study of different research paradigms, some theoretical ideas of interaction of myth and education in a demythological or remythological perspective can be found in the few studies by F. Frobel, D. Lenzen, P. Freire, V.S. Bibler, A.M. Lobok and others.

However, a comprehensive study of the specific characteristics of the correlation of myth and education in a multi-level structure of the human existence has not been carried out yet. Thus, the current level of the problem development suggests a free research area and creates the prerequisites for the progressive deployment of the author's conceptual strategy.

The object of the study is myth and education as the phenomena of the human existence. The subject of the study is the convergence of myth and education in the deployment of an existential, cultural and social space of being.

The purpose of the study is to explicate the interdependence and interaction of myth and 
education as culture-forming principles in the overall structure of the human being and to develop an integrated model of their interpretation in three projections corresponding to the existential, cultural and social levels of being and revealing the structural and substantial aspects of myth and education and their functional characteristics.

\section{Methodology of the study}

The specificity of the methodological basis of the studies of such complex (in multifunctional and multidimensional terms) phenomena as myth and education is in a special integrative status of disciplinary approaches and methods of different conceptual and theoretical paradigms that help to solve the problems of a complex level of cognition.

A key role in the study is played by a paradigm of the human being as presence, developed by M. Heidegger (Heidegger, 1997), as well as by a set of ideas about the co-existence with the Other, presented in the theoretical and philosophical works by M.M. Bakhtin, L. Binswanger, B. Waldenfels, J. Lacan, E. Levinas. The conceptual ideas of S.E. Iachin (Iachin, 2001) about the three threshold forms of the human existence (existential, cultural and social) concretized in accordance with the objectives of this study are of methodological significance. The theoretical and methodological grounds for the features of existential aspects of the interaction of myth and education are based on the concept of spiritual communication created by K. Jaspers (Jaspers, 1994) and myth ontology by A.F. Losev (Losev, 1994). An important role in determining the existential status of education was also played by methodological settings of the hermeneutic tradition.

Philosophical synergetic ideas formed the foundation of the interpretation of culture as a complex self-organizing system and identification of characteristics of the nonlinear dynamics of culture and participation of myth and education in it. The study of a cultural-semiotic model of the interpretation of myth and education was carried out based on the theoretical developments by Iu.M. Lotman (Lotman, 1992) aimed at identifying the specifics of culture as a universe of the semiotically manifested meanings. Symbolic forms that contain the semantic content of myth and education in the area of culture and society are analyzed through the prism of the general provisions of the structural and semiotic approach. The specificity of the social and communicative nature of myth and education is identified in the context of the theory of communicative action by J. Habermas (Habermas, 2000).

\section{Discussion}

In the multi-level structure of the human being, both myth and education are the universal constitutive forms, in which the specific content of human life is born, experienced, finds its symbolic manifestation and is represented in a social environment. Completing the task of "disclosure of being" (M. Heidegger), myth and education are based on the existential experience that is embodied in a sign-symbolic form plunging into the inter-subjective semantic space and then acquires the alienated existence in the institutional space of joint being. Every moment of transition from one threshold form to another is accompanied by the increasing complexity and the transformation of the original universal manifestation of the "element of being", its inevitable deformation and distortion, and the emergence of various "transformed forms".

Reconstruction of the most significant and dominant features of myth and education allows us to present three interpretative models (ontological-existential, cultural-semiotic, socialcommunicative), each of which identifies the essential integral parameters of myth and education reflected in the research tradition. 
At the existential level, being appears in its pure essence that has not yet been transformed and modified by the interaction with other layers and sections of reality. It is at this level where we can identify, "highlight" the fundamental properties of being, as well as the key elements constituting the existence and its manifestations in the world. A person in the existential analytics is conceived not as a substance, not as a thing among things, but as a special kind of things in existence, the main mode of existence of which is the "question of Being" (M. Heidegger). The human being is "being-in-possibility", it is never completed, and the "incompleteness" of the existence, its openness and projectivity find expression in this. The existential experience guarantees the authenticity of the human existence and, therefore, the possibility of implementation of being.

At the existential level of being the genetic origins and functions of myth and education are defined in the framework of the life-world as the horizon of the "world-pre-given", in the experience of which the initial forms of human being and consciousness are crystallized.

The existential nature of myth is revealed in a situation of trust, in which the primary opposition "I-Other" occurs and becomes actual. It is based on the internal experience of the existential of trust, which is the beginning of the "disclosure" of being-in-possibility, the development and selfcreation of a person, overcoming his abandonment in the world. Myth is a form of preserving the semantic integrity of the universe falling into a subject and an object. Myth outlines the semantic horizon that unfolds the cultural and historical experience of the human being and implements some type of a specific ethnic and cultural program.

The space formed by myth has structural and semantic indifference. Myth still has no separation between the real and the ideal, visibility and truth, the illusory and the actually perceived, between an image and a thing; it lacks the dualism of body and soul, the separation of a subject and an object, "everything may be turned into everything" in it (E. Cassirer). By keeping itself and the Other in a single existential space, myth sets the prospect of potentially infinite semantic production and meaning-making.

The essential features of education at the existential level of being are determined based on the characteristics of manifestation of the existential of understanding. Understanding is interpreted as an existentially-directed process, which helps to build a value-semantic position of personality integrating knowledge of the world and attitude to the world. As opposed to the multiple variations of existential projects of the Other, the existential experience, projection and the fundamental choice by a personality of its space, its path, its existence are carried out in education.

At the existential level, education, like myth, occurs situationally: the establishment of semantic relationships within the limited, closed area can be changed at any time as a result of presentation of a new meaning, the meeting with the new Other. Therefore, the formative borders of education as "its" space of the "understanding" being are flexible and flickering. In the space of education as a form of the "understanding" being may involve meanings of any subject spheres and fields of culture. In this regard, education is also similar to myth that arranges the independent territory of the primary semantic distinctionexperience.

At the existential level, myth and education represent two successive stages in the formation of being-in-possibility and form the necessary conditions for the subsequent construction of cultural spheres, their semantic determination and content. Myth and education to the full extend fulfil their existential purpose in the process of existential communication serving 
as the foundation of authentic human relations, as the most important event in the person's selfdetermination in the world (Savelova, 2010: 92132).

As opposed to the existential level, at the cultural level, the element of being manifests itself in certain forms, acquires specificity and "appearance". In the framework of the study culture is understood as the ultimate level of deployment of the human existence, the structure and content of which is determined by the processes of meaning-making and semiotization. Joining the existential and social sphere of being, culture transfers the inner feeling of the existential semantic experience into the form of characters and texts focused on communication with the Other(s). In moving from the inner experience of being to the external deployment in the space of culture, the branching of meaning, its sophistication and repeated multiplication occur. In the endless production of a "sign of signs", a real experience of being slips, diffuses and gets lost in a variety of objectifications.

At the cultural level of being, myth and education manifest and interact in four main aspects: structural-functional, semiotic, dynamic, communicative.

The structural-functional aspect allows us to analyze the embeddedness of myth and education in the structure of culture as a complex structural system based on the processes of meaning-making. Moving to the space of culture, myth "turns" into the semiotically marked structural configuration with a pronounced semantic centre and unstable semantic periphery. A constant core of myth contains a dominant meaning inscribed in the opposition "I-Other". This meaning is selected and fixed in the cultural tradition in accordance with certain historical, philosophical, psychological, political and other settings. Around it, in a peripheral zone, there is a diffusive "cloud" of border meanings that are the other probabilistic pole of opposition and are potentially able to change, interfere or even fall away from the main part.

Such a "transformed" form of myth that is a symbolic equivalent of the mythological experience of existential communication with the Other is included in the network of actual and potential cultural interactions, and its main feature as the minimum unit of mythological discourse is the presence of a "trace" of the Other defined through the presence of explicit or implicit connotative values.

Each mythological meaning is semantically polysemous; it carries the prints, echoes of multiple images of the Other - meanings, emotions, actions, situations, feelings and experiences. Therefore, even when the sociocultural situation changes, myths remain stable and constant for different cultures and societies in different historical periods, because a new facet of the semantic image of the Other, new shades of its potentially infinite being can be manifested and actualized in them.

Accumulating and concentrating the possible combinations and configurations of meanings, myth creates its own semantic "history" and performs a cultural function of accumulation. By implementing a different function - the function of integration - myth connects the numerous complexes of cultural meanings and creates their new correlations and recombinations. Such mythological structures form an inhomogeneous semantic field that contains potential reserves of primary semantic complexes of culture in general.

Mythological meanings may be manifested in any sphere of culture (art, religion, social relationships, everyday life, etc.), as well as be present in a personal mental space of each person. For them, in culture, there is no specific space of being: they are legalized at all levels and in all sub-systems of culture. 
At the cultural level, education, as well as myth, is substantially transformed and acquires a new structure and new functions - accumulation, translation, acculturation. "Transformation" of education is due to the fact that the existential nature of understanding, which is the basis of the educational process, is essentially important not only for the personal formation and selfdetermination, but also for the development and conservation of the entire system of culture. The more extensive and multidimensional configuration of culture becomes in the course of its evolution, the more new semiotic constructs increase its weight and complicate intra- and intersystem interactions, the more it needs its own system regulation and control. This means the need for the development of a "human of culture" with the correspondent knowledge, experience and technologies for the implementation of various activities necessary for the successful functioning of a certain type of culture.

On the one hand, education in the culture system maintains its status as a form of personal self-determination of a human in the horizon of the infinite variety of cultural meanings, and on the other hand, it is implemented as a form of the cultural identification of a person, by means of which he is immersed in the semantic world of his ethnic and cultural tradition and identifies himself with it. Education as one of the internal subsystems of culture sets certain limits, within which the implementation of an infinite number of options for semantic deploying of myth is carried out. However, the semantic field of education will include those complexes of meanings semiotically embodied in the form of signs and texts that are relevant to culture to the fullest extent and are marked as fundamental, basic and dominant. Signs, texts, examples and models are prepared for translation and are controlled by culture in order to preserve and create the appropriate type of person.
Thus, the process of divergence of education into the personal and acculturating variants that was found at the cultural level violates its existential and semantic integrity: the existential necessity of education of a person as a subject and a creative "phenomenon" of being comes into conflict with the need for education of a person as a "manager" of cultural processes (Savelova, 2010: 133-154).

The semiotic aspect characterizes the features of the sign representation of myth and education in the semantic universe of culture. The most appropriate type of a sign to represent the mythological "trustworthy" experience is a symbol, through which the potential semantic infinity of myth can be expressed.

Fixing one or another semantic facet of the mythological correlation with the Other, the symbol concentrates the volume and complexity of mythological signifiers and enters the mythological meaning in the semantic universe of a particular cultural tradition. At this, the symbol retains the ability to resume mythological relations and connections that are in a "sleep" mode.

Features of perception and decryption of the symbol are associated with the interpreter's ability to use different codes for the complete reconstruction of the possible mythological images of the Other. The semantic structure of the symbol is multi-layered and is designed for the active inner work of the perceiver: meaning of the symbol cannot be decrypted by a simple effort of mind, it is necessary to "get the feel of it". Detection and identification of a signifier can be carried out only with a thorough knowledge of the cultural context provoking the "collapse" of mythological signifiers depending on the use of different decryption codes.

The symbol structure has a moment of connection of different sign systems of semiosphere covering different codes, languages, 
cultural worlds, trends and human activities. Being the most important meaning-carrying units of semiosphere, within a particular cultural system or an individual sphere, symbols form a semantic network, by means of which they preserve deep culture-forming meanings of myth, actualize them and acquire new ones, moving from one historical era to another.

Terms of generation of knowledge and meaning in the educational process and semiotic specificity of this process can be represented by the example of the two variants of education personal and acculturating.

The personal variant of education is seen as a specific process of self-determination and self-consciousness of a person, personal growth through the supposition of meaning - an intermediary between the cognizing, thinking subject and the cognizable object. Therefore, the personal education supposes disengagement, "deployment" of a symbolic structure of meaning, detection of its deep mythological formations, experience of the existential situation of trust, establishment of new structural links and relations, implementation of its own, responsible choice of meaning.

In the acculturating variant, the educational "content" will emerge as a result of simplification, reduction of the variety of the semantic volume of culture to a certain limit conditioned by the needs of culture at a particular stage of its development. The central, ordered area of the education system will be cultural patterns - special stable sign structures of an indexical character that include simplified, schematized complexes of meanings reflected in some tradition as culturally significant. If the function of the symbol as a sign is marking the infinite set of possible meanings, then the index as a sign of the "frozen", invariant meaning brings up a certain model in mind, defines the usual method of its cultural existence and provokes familiar operation.
The interaction with the cultural patterns in education can occur in two variants. Firstly, mythological meanings fixed in the cultural patterns can be disengaged and redefined, and new variants of semantic images of the Other "folded" in the symbol can be actualized and moved from the peripheral regions. As a result of such critical perception of cultural patterns, the main focus in the functioning of education is on the formation of the semantic attitude, rather than ready-made "recipes" of cultural activity. Secondly, the cultural patterns themselves can be presented in a particular historical system of education as standardized and reduced meanings and semantic combinations strictly required for the development, and, accordingly, for a successful entry into the world of a particular cultural tradition. The cultural patterns are correlated with the existing or newly created cultural meanings. They are the basis in establishing new semantic connections or in reorganization of the existing ones. The result of the educational process in this case becomes knowledge as an isolated and culturally formalized product involving the unconditional acceptance and translation of mythological meanings of cultural patterns in the form of cultural stereotypes.

Choosing one or the other strategy of its functioning, education either operates with an infinite spectrum of meanings in the free mode proposed by culture or "squeezes" it to the typed schemes-patterns generating diametrically opposed resultants - meaning or knowledge. Being present in the reduced form in the cultural patterns, myth, on the one hand, connects the cultural and educational space into a unified whole through the support meanings-indexes, and on the other hand, it carries a potential charge of the polyvariant semantic disclosure, thus, keeping education from stagnation (Savelova, 2010: 154-178). 
The dynamic aspect focuses on the role of both phenomena in the processes of semantic entropy and negentropy in culture.

As with all open systems, the states of chaos and order, stability and disorganization, entropy and negentropy in culture and its areas interchange with each other. The level of entropy in various spheres of culture is determined by the capacity for the development and inclusion in the system connections of the new semantic material eliminating gaps and dissonances arising in intra interactions, as well as the ability to create and maintain a potentially infinite reserve of meanings in a standby mode.

Myth reveals its presence in the moments of structural destabilization of culture offering two variants of behaviour. In an inversion variant, the opposition of semantic poles "I-Other" is removed causing "collapse" of endless semantic configurations. The mediation variant offers to "remove" the problem of the entropy semantic chaos through the formation of a zone of synthetic intermediate meanings. In a situation of negentropy, myth folds up the process of participation and rigidly fixes stable semiotic constructs preventing their development.

Dynamic processes in education occur in different forms in different ways. In the personal education to a greater extent there is an increased risk of unstable, entropy states, and therefore there is a need for myth as a kind of a "key" to the discovery of multiple meanings and their creative operation. In acculturating education there is a trend to negative entropy that is manifested through the preference of organized and interrelated cultural patterns that are sanctioned by respective culture and express its basic, stable constants (Savelova, 2010: 178-193).

The communicative aspect of the interaction of myth and education is a ritual and a game as the two most important, specially organized and sanctioned by culture technologies of reactivation of the creative (meaning-generating) and normative (meaning-preserving) functions of myth in a communicative space of culture. Both the ritual and the game are the methods of situational return to the existential great-experience of the integrity and unity of the world through the actualization of myth. In acculturating education the ritual (normative) strategy is realized to the full, in personal education it is the game (creative) strategy (Savelova, 2010: 194-214).

At the social level, there is even greater depersonalization of being, there is a risk of its distortion. The social environment is primarily focused on the reproduction and distribution of the cultural and social patterns, the formation of stable norms and rules of social interaction, the support of social institutions as a condition for the organization of joint being.

The nature of the interaction of myth and education at the social level of being is determined by the specificity of relations "system - lifeworld". As part of the cultural patterns, myth is included in the content of the life-world, it creates conditions for social communication, enables multiple versions of relationships, including those leading to consensus and understanding. The destructive role of myth is related to its distortion, "transformation" into the form of social ideology.

Education has the formal status of a social institution and is determined by the presence and consolidation of system connections and interactions, and its expansion led to the disappearance of a "worldly", communicativesemantic basis. Implementation of the personal existential project is made dependent on an external "power" discourse, ideological biases and manipulation strategies. Continuous distribution in the education system of mythological complexes of meanings of the life-world, on the one hand, enhances the semantic range of the Others, and on the other hand, creates favourable conditions 
for the levelling of personal communicative properties by offering a "complete" image of the Other. Resistance to manipulative "violence" can be accomplished through the reflexive destruction of an ideological "transformed" form of myth and the formation of its reasoned communicative "speech" (Savelova, 2010: 217-247).

\section{Conclusion}

The study established the semantic, structural and functional correlation between myth and education in consistent deployment of the existential, cultural and social levels of human being, as well as the author's approach to the use of the creative potential of myth in the technology of acculturating education through simulation in the educational space of semantic "possible" worlds (Savelova, 2010: 266-305).

Changing the grounds of the contemporary socio-cultural view of the world puts to the fore the problem of transformation of education into the mechanism of the development of culture, which, in turn, requires the development in the younger generation of skills of acculturation, reflective analysis, creative thinking. The reorientation of the socio-cultural paradigm allows us to create a fundamentally different educational reality, in which the universe of culture appears as the equal co-existence of many alternative, plural pictures of the world, none of which is privileged in relation to the others.
In the new-temporary type of education myth, as part of the cultural patterns, creates a kind of a "third world" - a network of cultural stereotypes that underpin the formation of a unitary, unopposed, in fact, mythological picture of the world. A meaning-creative potential of myth can be used in the technology of contemporary acculturating education, the basic idea of which is the formation in a communicative space of the formation of a personal "possible" world. Major cultureforming phenomena that form the basis of the proposed technology (everyday life, surprise, dialogue, problem situation, reflection, "estrangement", "possible world") are included in the theoretical and methodological basis and the practical educational activities of some modern philosophical and pedagogical concepts.

Thus, learning to build "possible" worlds, a person ceases to be a "character" determined by culture, becomes familiar with the cultural experience, and acquires the cultural and educational competence, the ability to understand multivariance of the world, its ambiguity. In this case, the creative energy of myth is directed to the creation of its own subjectivity and filling the void space between the finished meanings with its own personal social and cultural meaning transforming the process of education from the myth-generating into the myth-creative.

\section{References}

Habermas, Ju. (2000) Moral'noe soznanie i kommunikativnoe deistvie [Moral consciousness and communicative action]. Saint-Petersburg, Nauka, $377 \mathrm{p}$.

Hajdegger, M. (1997) Bytie i vremia [Being and time]. Moscow, Ad marginem, $451 \mathrm{p}$.

Iachin S.E. (2001) Chelovek $v$ posledovatel'nosti sobytii zhertvy, dara i obmena [A man in a succession of events of a victim, gift and exchange]. Vladivostok, Dal'nauka, $279 \mathrm{p}$.

Jaspers, K. (1994) Smysl i naznachenie istorii [Meaning and purpose of history]. Moscow, Respublika, 527 p.

Losev, A.F. (1994) Mif - Chislo - Sushchnost' [Myth, number and essence]. Moscow, Mysl'. $919 \mathrm{p}$. 
Lotman, Iu.M. (1992) Kul'tura i vzryv [Culture and explosion]. Moscow, Progress; Gnozis, $270 \mathrm{p}$.

Savelova, E.V. (2010) Mif i obrazovanie v strukture chelovecheskogo bytiia i kul'tury [Myth and education in the structure of human being and culture]. Khabarovsk, Dal'nevostochnyi gosudartvennyi gumanitarnyi universitet, $346 \mathrm{p}$.

\title{
Миф и образование в становлении человеческого бытия: экзистенциальное, культурное, социальное пространство
}

\author{
Е.В. Савелова \\ Хабаровский государственный институт культуры \\ Россия, 680045, Хабаровск, ул. Краснореченская, 112
}

В настоящей статье автор представляет результаты исследования мифа и образования как универсальных феноменов человеческого бытия и культуры. Автор обращается к ряду фундаментальных методологических подходов, совокупность которых позволяет обосновать определенные закономерности функиионирования мифа и образования в становлении человеческого бытия и его формогенеза. Выявлена экзистенциальная основа проявлений мифа и образования в со-бытийном пространстве человеческого бытия. Исследованы истоки и генезис культурного бытия мифа и образования и их смыслообразующая роль. Определена специфика семиотической репрезентачии мифа и образования в универсуме культурных смыслов. Проанализированы характерные черты структурно-функиионального, динамического и коммуникативного аспектов взаимодействия мифа и образования в пространстве культуры. Обосновано участие мифа и образования в сочиально-коммуникативных процессах и современной образовательной практике.

Ключевые слова: миф, образование, человеческое бытие, экзистенция, культура, социум.

Научная специальность: 24.00.00 - культурология. 